\title{
Characterization of Plasmids from Antibiotic-resistant Shigella Isolates by Agarose Gel Electrophoresis
}

\author{
By A. F. JAMIESON, D. A. BREMNER \\ Department of Pathology, University of Auckland School of Medicine, New Zealand \\ P. L. BERGQUIST AND H. E. D. LANE \\ Department of Cell Biology, University of Auckland, New Zealand
}

(Received 27 November 1978)

\begin{abstract}
Gel electrophoresis of DNA from 95 clinical isolates of Shigella sonnei and Shigella flexneri resistant to antibiotics revealed a heterogeneous plasmid population. Most of the plasmids were smaller than 6 megadaltons (Mdal). Six $S$. sonnei isolates with the most common antibiotic resistance pattern were characterized. They had two plasmids in common: one was a self-transmissible $\mathrm{Fi}^{+}$plasmid of $46 \mathrm{Mdal}$ encoding tetracycline resistance, while the other was a $5.5 \mathrm{Mdal}$ non-conjugative plasmid encoding resistance to streptomycin and sulphafurazole. In addition, several cryptic plasmids ranging in size from 1.0 to $24.5 \mathrm{Mdal}$ were present. Mobilization of the 5.5 Mdal SuSm plasmid and a 1.0 Mdal cryptic plasmid was demonstrated with all six $S$. sonnei isolates during conjugation. This mobilization was mediated by the $46 \mathrm{Mdal}$ self-transmissible $\mathrm{Fi}^{+} \mathrm{R}$ plasmid and also by a $24.5 \mathrm{Mdal} \mathrm{Fi}^{-}$ plasmid carrying no known drug resistance determinants.
\end{abstract}

\section{INTRODUCTION}

Recent studies (see, for example, Møller et al., 1978) have shown that most naturally occurring strains of the Enterobacteriaceae contain small circular non-conjugative plasmids ranging in size from 0.8 to 10 megadaltons (Mdal). The molecular weight and base composition of these plasmids vary even within a single bacterial species (Rush et al., 1969; Møller et al., 1978). The effects of some of these plasmids have been determined, for example, drug resistance (Smith et al., 1974), colicin production and immunity (Porter et al., 1973) and antigen production (Bak et al., 1972). The role of the remainder is not established although some may contribute to pathogenicity (Christiansen et al., 1973; Falkow, 1975).

The widespread occurrence of these small molecules could be explained by efficient transfer systems responsible for their dissemination. Considerable genetic information is required to code for a complete conjugation system. For example, the transfer operon of the sex factor $\mathrm{F}$ encompasses $15 \mathrm{Mdal}$ of DNA (Achtman \& Helmuth, 1975). Thus plasmids considerably smaller than $15 \mathrm{Mdal}$ might be unable to transfer their DNA by conjugation unless they were mobilized by a self-transmissible plasmid. Mobilization of some of these small plasmids encoding drug resistance or colicin production by large self-transmissible plasmids has been observed (Smith \& Linggood, 1970).

The use of gel electrophoresis techniques (Meyers et al., 1976) has simplified the detection of small plasmids conferring no observable phenotype. In this paper, we describe the use of these techniques to examine the varied plasmid population which exists in Shigella isolated from clinical material, and to characterize systems responsible for the transfer of small non-conjugative plasmids among these bacteria. 


\section{METHODS}

Shigella sonnei and Shigella flexneri isolates were obtained from the New Zealand National Health Institute, Wellington, or isolated from patients at Auckland Hospital. These isolates were resistant to one or more of the following agents: sulphafurazole (minimum inhibitory concentration $>500 \mu \mathrm{g} \mathrm{ml}^{-1}$ ), ampicillin, tetracycline, chloramphenicol, streptomycin and cephaloridine (minimum inhibitory concentration for each $>32 \mu \mathrm{g} \mathrm{ml}^{-1}$ ).

Transfer of plasmids from $S$. sonnei to Escherichia coli $\mathrm{K} 12$ was attempted by conjugation with nalidixic acid-resistant derivatives of J5-3 (F- met-63 pro-22) or PB1395 (F- met supE supF hsdR) as described by Bremner (1978). Transformation of plasmids to $\mathrm{C} 600$ ( $\mathrm{F}^{-}$thi-1 thr-1 leu-6 lac Y1 supE44 tonA21) or PB1395 was done essentially as described by Mandel \& Higa (1970). PB501 ( $\mathrm{F}^{-}$galT12) was used as the recipient in $\mathrm{K} 12 \times \mathrm{K} 12$ crosses.

The fertility-inhibiting (Fi) character of conjugative Shigella plasmids was assessed by examining exconjugant strains containing the conjugative plasmid and $\mathrm{F}^{\prime}-$ gal $^{+}(\mathrm{F} 8)$ for susceptibility to lysis by the F-specific phage R17.

Plasmid DNA was prepared by the method of Meyers et al. (1976). Care was taken to prevent shearing of chromosomal DNA before its removal by differential salt precipitation. This precaution significantly reduced the concentration of chromosomal DNA present in cleared lysates, allowing detection of 6 to $10 \mathrm{Mdal}$ plasmids which can be obscured by chromosomal DNA. Open circular and linear DNA were removed by the method of Zasloff et al. (1978).

Digestion of plasmid DNA by restriction endonuclease EcoR1 was carried out at $37^{\circ} \mathrm{C}$ for $1 \mathrm{~h}$ in a reaction mixture containing $20 \mu \mathrm{l}$ DNA (dissolved in $10 \mathrm{~mm}$-Tris/HCl, pH 8.0, 1 mM-EDTA), $2 \mu 1$ concentrated enzyme buffer $\left(0.9 \mathrm{M}-\mathrm{Tris} / \mathrm{HCl}, \mathrm{pH} 7 \cdot 4,0.1 \mathrm{M}-\mathrm{MgCl}_{2}\right)$ and $2 \mu \mathrm{l} E c o \mathrm{R} 1$ ( 1 unit $\mu 1^{-1}$, prepared as described by Tanaka \& Weisblum, 1975). Agarose gel electrophoresis was carried out in a horizontal gel apparatus similar to that described by McDonell et al. (1977) for $3 \mathrm{~h}$ at $135 \mathrm{~V}$ in 0.7 or $0.85 \%$ (w/v) agarose (Sigma A6877) in borate buffer (Meyers et al., 1976). After electrophoresis, gels were placed on a Blak-Ray UV transilluminator screen (Ultraviolet Products, San Gabriel, Calif., U.S.A.) and photographed with Agfapan 400 film, which was developed using a reversal process.

Radioactive labelling of RSF1010 (R300b) DNA from PB1379 (RSF1010/F- thy A36 deoC2) with $\left[{ }^{32} \mathrm{P}\right] \mathrm{dATP}$ was by nick translation as described by Jeppesen et al. (1976). Hybridization of ${ }^{32} \mathrm{P}-\mathrm{labelled}$ DNA to plasmid DNA separated in agarose gels and transferred directly to nitrocellulose filters was carried out using a modification of the method of Southern (1975). Hybridization was in $50 \%$ formamide $/ 2 \times \mathrm{SSC}$ buffer ( $\mathrm{SSC}$ is $0 \cdot 15 \mathrm{M}-\mathrm{NaCl} / 0 \cdot 015 \mathrm{M}$-trisodium citrate).

\section{RESULTS}

Demonstration of a heterogeneous plasmid pool in clinical isolates of Shigella

Antibiotic-resistant isolates of Shigella sonnei and Shigella flexneri obtained from geographically distinct areas of New Zealand between 1972 and 1976 were screened for the presence of plasmid DNA. Cleared lysates from 95 isolates were electrophoresed in agarose gels. Figure 1 shows the distribution of the molecular weights of plasmid molecules from these isolates. All isolates examined contained at least two plasmids of different molecular weights; some contained as many as ten. Although sizes ranged from 1 to $70 \mathrm{Mdal}$, the majority of plasmids were smaller than $6 \mathrm{Mdal}$.

Open circular (OC) as well as covalently closed circular (CCC) forms of the plasmid molecules were present in cleared lysates prepared as described by Meyers et al. (1976). Open circular DNA was distinguished from CCC DNA by removal of OC plasmid (and linear chromosomal) DNA by extraction with acid phenol (Zasloff et al., 1978) as shown in Fig. 2.

\section{Molecular weight determination of the plasmids from six antibiotic-resistant S. sonnei isolates}

To investigate the extent of mobilization of small plasmids from Shigella, we examined six isolates each containing plasmids ranging in size from 1 to $45 \mathrm{Mdal}$. These isolates were representatives of the predominant class of antibiotic-resistant $S$. sonnei detected between 


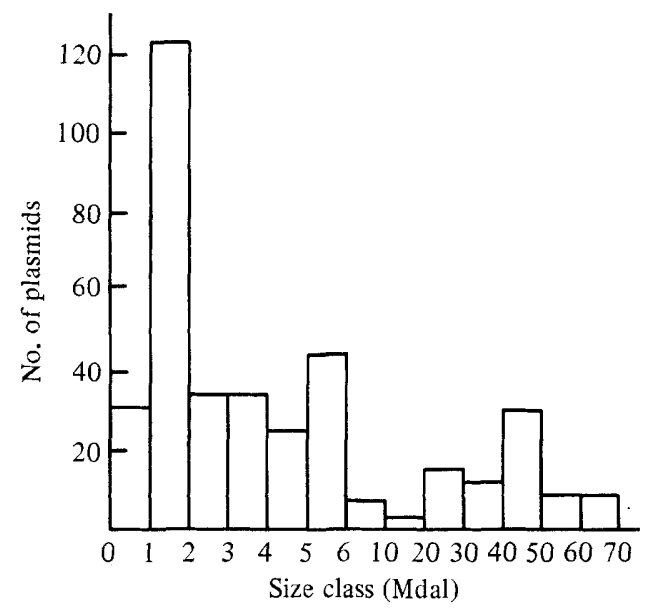

Fig. 1. Histogram of the distribution of molecular weights of CCC plasmid molecules from 95 $S$. sonnei and $S$. flexneri isolates resistant to one or more antibiotics. Molecular weights were calculated from relative electrophoretic mobilities as described in Fig. 3.

Table 1. Molecular weights of plasmids present in six antibiotic-resistant S. sonnei isolates

Molecular weights were determined as described in Fig. 3. The antibiotic resistance pattern of all isolates was ApTcSuSm.

\begin{tabular}{|c|c|c|c|c|c|c|c|c|c|c|c|}
\hline \multirow{2}{*}{ Isolate } & \multicolumn{11}{|c|}{ Plasmids present (Mdal) } \\
\hline & & & & & & & & & & & \\
\hline $\mathrm{SH} 1$ & 46 & & $5 \cdot 5$ & & & $3 \cdot 7$ & & 1.9 & 1.6 & $1 \cdot 2$ & $1 \cdot 0$ \\
\hline SH7 & 46 & & $5 \cdot 5$ & $4 \cdot 8$ & $4 \cdot 2$ & $3 \cdot 7$ & $2 \cdot 0$ & 1.9 & $1 \cdot 6$ & $1 \cdot 2$ & $1 \cdot 0$ \\
\hline SH16 & 46 & & $5 \cdot 5$ & $4 \cdot 8$ & & & & $1 \cdot 9$ & $1 \cdot 6$ & & $1 \cdot 0$ \\
\hline SH20 & 46 & & $5 \cdot 5$ & & & & & $1 \cdot 9$ & $1 \cdot 6$ & $1 \cdot 2$ & $1 \cdot 0$ \\
\hline SH28 & 46 & $24 \cdot 5$ & $5 \cdot 5$ & & & $3 \cdot 7$ & & & 1.6 & $1 \cdot 2$ & 1.0 \\
\hline $\mathrm{SH} 34$ & 46 & $24 \cdot 5$ & $5 \cdot 5$ & & & & & $1 \cdot 9$ & 1.6 & $1 \cdot 2$ & $1 \cdot 0$ \\
\hline
\end{tabular}

1972 and 1974 and were resistant to ampicillin (Ap), tetracycline (Tc), sulphafurazole (Su) and streptomycin $(\mathrm{Sm})$. Table 1 lists the molecular weights of the plasmids present in the isolates as determined by gel electrophoresis. Wells B and C of Fig. 3 show DNA from two isolates: strain SH34 (well C), for example, contains seven plasmids $(46,24 \cdot 5,5 \cdot 5,1 \cdot 9,1 \cdot 6$, $1 \cdot 2$ and $1.0 \mathrm{Mdal})$.

\section{Identification of plasmids specifying antibiotic resistance}

$\mathrm{R}$ plasmids were identified following transformation of antibiotic resistance to Escherichia coli $\mathrm{K} 12$. Tc and SuSm resistance could be transferred independently to $E$. coli by transformation of $\mathrm{C} 600$ with DNA from each of the six $S$. sonnei isolates. Gel electrophoresis of DNA from the $\mathrm{Tc}^{\mathrm{R}}$ and $\mathrm{SuSm}^{\mathrm{R}}$ transformants revealed that the plasmids present in the transformed cells were of 46 and $5 \cdot 5 \mathrm{Mdal}$, respectively. Transformation of ampicillin resistance to either $\mathrm{C} 600$ or $\mathrm{PB} 1395$, a restriction-negative $(h s d R)$ mutant of $E$. coli, was not observed.

\section{Characterization of $R$ plasmids}

Comparison of the numbers and sizes of the DNA fragments produced by digestion of any two plasmids by a sequence-specific nuclease can be used as a measure of the relatedness of the plasmids (Thompson et al., 1974). The $46 \mathrm{Mdal}$ Tc $\mathrm{R}$ plasmids from each of the six 


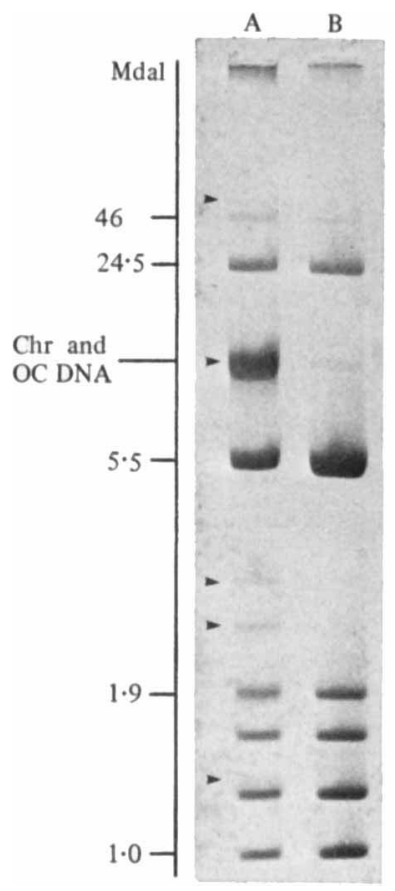

Fig. 2

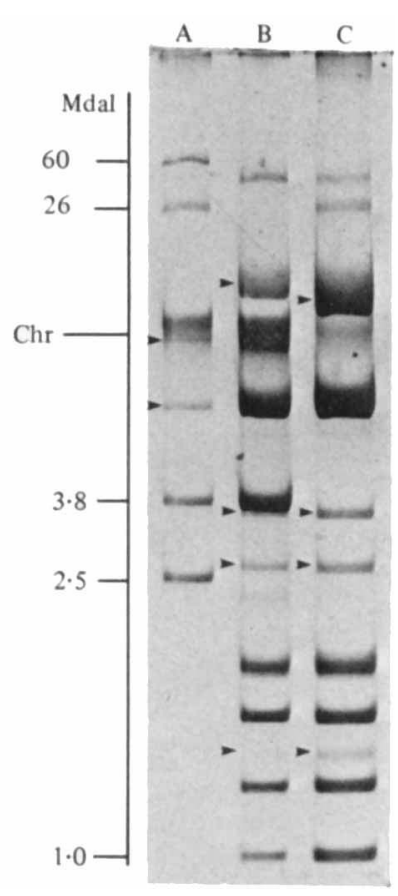

Fig. 3

Fig. 2. Electrophoresis in $0.7 \%$ agarose of DNA from a cleared lysate of $S$. sonnei isolate SH34 before and after extraction with acid phenol. Arrows indicate the slower running OC DNA. The CCC DNA of the fourth smallest plasmid obscures the OC DNA of the second smallest plasmid. Chr indicates the banding position of chromosomal DNA. A: SH34 DNA before acid phenol extraction. B: One acid phenol extraction of the SH34 cleared lysate in well A resulted in removal of $>90 \%$ of OC and linear DNA. The efficiency of recovery of plasmid DNA decreased with increasing size for plasmids greater than $25 \mathrm{Mdal}$ (see $46 \mathrm{Mdal}$ plasmid).

Fig. 3. Electrophoresis in $0.7 \%$ agarose of DNA from cleared lysates of $S$. sonnei isolates resistant to Ap, Tc, Su and Sm. Arrows indicate OC DNA not obscured by CCC DNA. Chr indicates the banding position of chromosomal DNA. Molecular weights were calculated from the mobilities of plasmids relative to the mobilities of the plasmids of known molecular weights in well A. Additional estimates of the sizes of the $46,5.5$ and 1.0 Mdal plasmids in wells B and C were obtained by comparison of the mobilities of their linear fragments produced on digestion by EcoR 1 with the markers derived from $E c o$ R 1 digestion of R100-1 and bacteriophage $\lambda$ (see, for example, Figs 4 and 5). A: DNA standards; R100-1 (60 Mdal), R6K (26 Mdal), pMB9 (3.8 Mdal) and pBR322 (2.5 Mdal). B: DNA from $S$. sonnei isolate $S H 1 ; 46,5 \cdot 5,3 \cdot 7,1 \cdot 9,1 \cdot 6,1 \cdot 2$ and $1 \cdot 0$ Mdal plasmids present. C: DNA from $S$. sonnei isolate SH34; 46, 24.5, 5.5, 1.9, 1.6, 1.2 and 1.0 Mdal plasmids present.

S. sonnei isolates gave identical sets of fragments on digestion with EcoR1 (Fig. 4). The patterns are similar to the EcoR1 pattern for the RTF portion of R100-1 obtained by Chandler et al. (1977). Similarly, the 5.5 Mdal SuSm R plasmids present in each of the six isolates were all cut once with $E c o \mathrm{R} 1$ to give a single fragment (Fig. 5). In addition, ${ }^{32} \mathrm{P}$ labelled DNA from the RSF1010 (R300b) plasmid isolated by Grinter \& Barth (1976) hybridized to each of the $5.5 \mathrm{Mdal} \mathrm{SuSm}$ plasmids from the six $S$. sonnei isolates, demonstrating a high degree of homology between these plasmids (Fig. 6).

The $46 \mathrm{Mdal}$ plasmid was shown to be $\mathrm{Fi}^{+}$and could be transferred to a second strain of $E$. coli $\mathrm{K} 12$ (PB501) by conjugation. The $5.5 \mathrm{Mdal}$ plasmid was not self-transmissible and could not be transferred to PB501 by conjugation from a strain containing this plasmid alone. 
A $\quad$ B $\quad$ C $\quad$ D

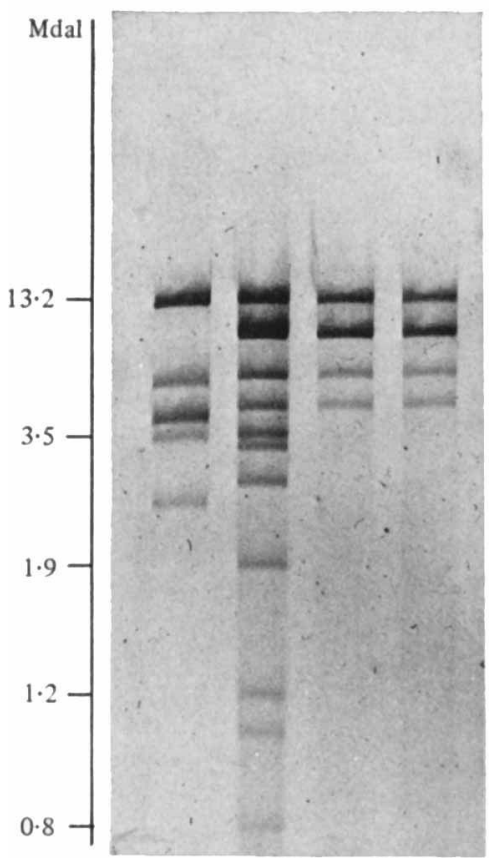

Fig. 4. Electrophoresis in $0.85 \%$ agarose of $E c o$ R 1 digests of $46 \mathrm{Mdal}$ Tc R plasmids from $S$. sonnei isolates. A: $E c o$ R1-digested $\lambda$ DNA. B: $E c o R 1$-digested R100-1 DNA. C: $E c o$ R1-digested DNA of the $46 \mathrm{Mdal} R$ plasmid present in a tetracycline-resistant $E$. coli constructed by transformation of C600 with SH1 DNA. D: EcoR1-digested DNA of the $46 \mathrm{Mdal}$ plasmid from SH34. The $46 \mathrm{Mdal}$ plasmids from all six $S$. sonnei strains examined gave identical sets of linear fragments on digestion with EcoR1.

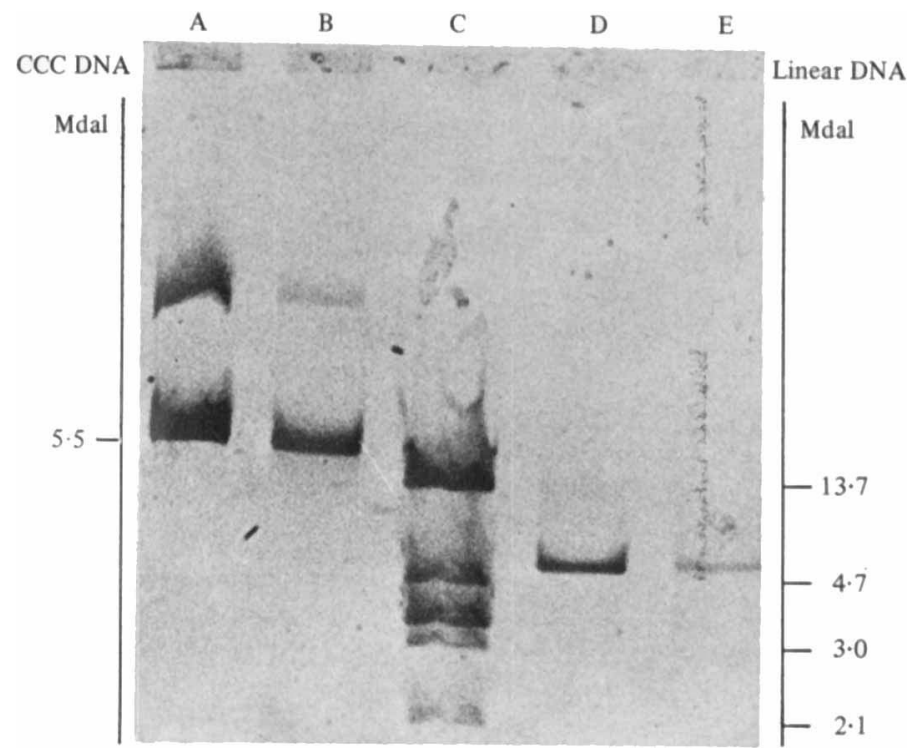

Fig. 5. Electrophoresis in $0.85 \%$ agarose of $E c o R 1$ digests of $5.5 \mathrm{Mdal}$ plasmids from $S$. sonnei isolates SH1 and SH34. A, B: Undigested DNA of 5.5 Mdal SuSm plasmids from E. coli C600 transformed with DNA from cleared lysates of SH1 (well A) and SH34 (well B). C: EcoR1-digested $\lambda$ DNA. D, E: EcoR1-digested DNA of the plasmids shown in wells A and B. Both the OC and $\mathrm{CCC}$ forms were cleaved once to give a $5.5 \mathrm{Mdal}$ fragment. 


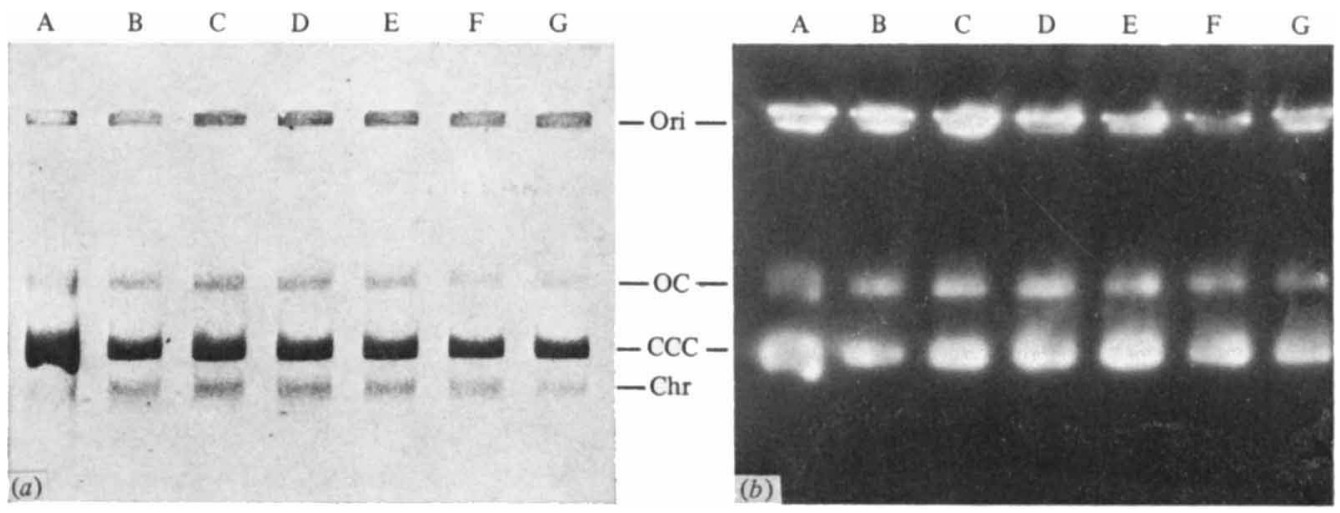

Fig. 6. Hybridization of ${ }^{32}$ P-labelled RSF1010 DNA to SuSm plasmids from $S$. sonnei isolates. (a) Bands present after electrophoresis of the SuSm plasmids through a $0.85 \%$ agarose gel before transfer to a nitrocellulose filter. $O C$ is $5.5 \mathrm{Mdal}$ open circular DNA, CCC is $5.5 \mathrm{Mdal}$ covalently closed circular DNA, Chr marks the banding position of chromosomal linear DNA and Ori marks the origin. (b) Autoradiograph of the nitrocellulose filter from the gel in (a) after hybridization with ${ }^{32}$ P-RSF1010 DNA. A: RSF1010. B to G: SuSm plasmids from SH1, SH7, SH16, SH20, SH28 and $\mathrm{SH} 34$, respectively.

\section{Mobilization of non-conjugative Shigella plasmids}

Conjugation of the six ApTcSuSm $S$. sonnei isolates with a nalidixic acid-resistant derivative of the $h s d R$ strain PB1395 gave rise to $\mathrm{Tc}^{\mathrm{R}}, \mathrm{SuSm}^{\mathrm{R}}$ and $\mathrm{TcSuSm}{ }^{\mathrm{R}}$ exconjugants. The restriction-negative recipient was employed to assess the extent to which transfer of plasmids was reduced as a result of degradation by recipient restriction endonucleases. Ampicillin-resistant exconjugants were not obtained $\left(<10^{-8}\right.$ per donor cell). The simplest explanation for the inability of ampicillin resistance to be transferred by conjugation or transformation is that ampicillin resistance is specified by chromosomal genes. DNA from $\mathrm{Tc}^{\mathrm{R}}, \mathrm{TcSuSm}^{\mathrm{R}}$ and $\mathrm{SuSm}^{\mathrm{R}}$ exconjugants was electrophoresed in agarose gels. $\mathrm{Tc}^{\mathrm{R}}$ cells contained a $46 \mathrm{Mdal}$ plasmid, $\mathrm{SuSm}^{\mathrm{R}}$ cells contained a $5.5 \mathrm{Mdal}$ plasmid and $\mathrm{TcSuSm}{ }^{\mathrm{R}}$ exconjugant cells contained both, indicating that the $46 \mathrm{Mdal}$ plasmid was able to mediate the transfer of the $5.5 \mathrm{Mdal}$ SuSm plasmid.

Transfer to $E$. coli of plasmids not encoding any known drug resistance markers was detected by electrophoresis of DNA from exconjugant clones. For example, Table 2 illustrates the inheritance of two unselected plasmids $(24.5$ and $1.0 \mathrm{Mdal})$ by $\mathrm{SuSm}^{\mathrm{R}}$ exconjugants from the cross SH34 $\times$ PB1395. Table 2 also shows that the use of an $\mathrm{HsdR}^{+}$ strain (a nalidixic acid-resistant derivative of J5-3) as a recipient resulted in a reduction in the proportion of $\mathrm{SuSm}^{\mathbf{R}}$ exconjugants carrying these unselected plasmids. Plasmid complements of representative exconjugants are shown in Fig. 7. In summary, all six $S$. sonnei isolates were able to mobilize the $1.0 \mathrm{Mdal}$ plasmid present in each. The two isolates containing a cryptic $24.5 \mathrm{Mdal}$ plasmid transferred this molecular species also. However, none of the remaining cryptic plasmids present in the six $S$. sonnei isolates were detected in any exconjugant resulting from crosses of these isolates with $E$. coli. For example, the 1.9, 1.6 and 1.2 Mdal plasmids were not transferred to any of $30 \mathrm{TcSuSm}^{\mathrm{R}}$ and $\mathrm{SuSm}^{\mathrm{R}}$ exconjugants derived from the cross $\mathrm{SH} 34 \times \mathrm{PB} 1395$.

Exconjugants containing the $46 \mathrm{Mdal}$ Tc plasmid, the $5.5 \mathrm{Mdal}$ SuSm plasmid and the 1.0 Mdal plasmid were able to transfer Tc and SuSm resistance to a second strain of $E$. coli (PB501). Electrophoresis of cleared lysates from these exconjugants showed that all three plasmids had been transferred to PB501, confirming that the $46 \mathrm{Mdal}$ self-transmissible plasmid is able to mediate the mobilization of both smaller molecular species. The two $S$. sonnei isolates containing the $24.5 \mathrm{Mdal}$ plasmid gave rise to $\mathrm{SuSm}^{\mathrm{R}}$ exconjugants at 
Table 2. Plasmid complements of $\mathrm{SuSm}^{\mathrm{R}}$ exconjugants selected after mating S. sonnei $\mathrm{SH} 34$ with E. coli $\mathrm{PB} 1395$ (hsdR) or E. coli $\mathrm{J} 5-3$ ( $\left.\mathrm{HsdR}^{+}\right)$

Cross
SuSm $^{\mathrm{R}}$ exconjugants
per donor cell
Unselected plasmids
in each exconjugant
class (Mdal)
4624.51 .0
24.51 .0
24.5
1.0
None

Total screened
SH34 × PB1395 (hsdR) $\quad$ SH34 × J5-3 $\left(\mathrm{HsdR}^{+}\right)$

$$
7 \cdot 5 \times 10^{-6} \quad 6 \cdot 0 \times 10^{-6}
$$

No. of exconjugants containing each unselected plasmid class

$\begin{array}{rr}11 & 7 \\ 14 & 7 \\ 0 & 12 \\ 5 & 0 \\ 0 & 4 \\ 30 & 30\end{array}$

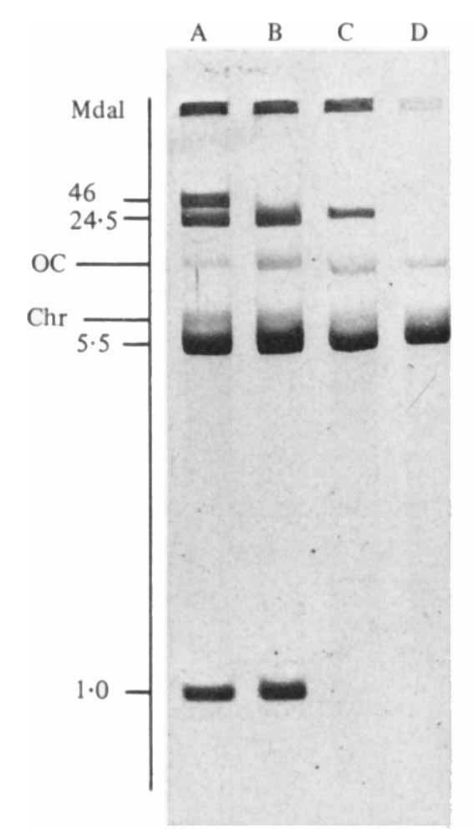

Fig. 7. Electrophoresis in $0 \cdot 7 \%$ agarose of DNA from $\mathrm{SuSm}^{\mathrm{R}}$ and $\mathrm{TcSuSm}^{\mathrm{R}}$ exconjugants obtained on mating $S$. sonnei SH34 with $E$. coli J5-3. A : DNA from a cleared lysate of a TcSuSm${ }^{\mathrm{R}}$ exconjugant containing the $46,24 \cdot 5,5 \cdot 5$ and 1.0 Mdal plasmids. B to D: DNA from $\operatorname{SuSm}^{\mathrm{R}} \mathrm{ex}^{\mathrm{C}}$ conjugants containing $24 \cdot 5,5 \cdot 5$ and 1.0 Mdal plasmids (well B), 24.5 and $5.5 \mathrm{Mdal}$ plasmids (well C) or 5.5 Mdal plasmid (well D). The small differences in the mobilities of the 24.5 and $5.5 \mathrm{Mdal}$ plasmids were caused by variations in the concentration of DNA in the cleared lysates (Meyers et al., 1976).

frequencies 20- to 50-fold higher than those obtained when any of the four S. sonnei isolates lacking this plasmid were used as donors. For example, $\mathrm{SuSm}^{\mathrm{R}}$ exconjugants arose at a frequency of $7 \cdot 5 \times 10^{-6}$ per donor cell from the cross SH34 $\times \mathrm{J} 5-3$, but were produced at a frequency of only $3 \times 10^{-7}$ per donor cell from the cross SH1 $\times$ J5-3. Since $24 \cdot 5 \mathrm{Mdal}$ of DNA is more than sufficient to encode an entire conjugational transfer system, exconjugants carrying the $24.5,5.5$ and 1.0 Mdal plasmids were mated with a second $E$. coli strain (PB501). All transferred SuSm resistance to PB501 at high frequencies $\left(10^{-3}\right.$ to $10^{-4}$ per donor cell). Electrophoresis of plasmid DNA from $10 \mathrm{SuSm}^{\mathrm{R}}$ exconjugants resulting from one of these crosses showed that the three plasmids were transferred to each exconjugant. 
Hence both the 24.5 and $46 \mathrm{Mdal}$ plasmids are able to mediate mobilization of the 5.5 and 1.0 Mdal plasmids. The $24.5 \mathrm{Mdal}$ plasmid was shown to be $\mathrm{Fi}^{-}$.

\section{DISCUSSION}

Isolates of the largest single class of resistant organisms among the 95 antibiotic-resistant Shigella isolates examined were resistant to tetracycline, sulphafurazole and streptomycin. Many other isolates were resistant to tetracycline or to sulphafurazole and streptomycin. The presence of a high proportion of plasmids with sizes in the range of 5 to $6 \mathrm{Mdal}$ and 40 to $50 \mathrm{Mdal}$ in these isolates suggests that the 5.5 and $46 \mathrm{Mdal}$ plasmids present in the six well-characterized strains are the major molecular species which mediate SuSm and Tc resistance in these bacteria. SuSm plasmids of $5.5 \mathrm{Mdal}$ occur frequently in other species of bacteria isolated in New Zealand. For example, all 10 of a representative sampling of SuSm-resistant Salmonella typhimurium isolates referred to the National Health Institute between 1972 and 1976 carried 5.5 Mdal non-conjugative plasmids which were cleaved once by EcoR1, hybridized to RSF1010 and conferred SuSm resistance on transformed E. coli cells (A. F. Jamieson \& P. L. Bergquist, unpublished results). Hence both the Salmonella and Shigella SuSm plasmids have similar properties to those described by Grinter \& Barth (1976).

The $S$. sonnei isolates also contained small non-conjugative plasmids which did not encode drug resistance and whose function is unknown. Similar small plasmids are commonly found in diverse bacterial taxa, for example, in Bacillus (Stahly et al., 1978), Neisseria (Mayer et al., 1974) and Pseudomonas (Pemberton \& Clark, 1973), as well as in species of Enterobacteriaceae (Møller et al., 1978) such as Shigella dysenteriae (Rush et al., 1969). Mobilization of one such plasmid, as well as the 5.5 Mdal SuSm plasmid, was demonstrated from six $S$. sonnei isolates. This mobilization was mediated by the $\mathrm{Fi}^{+}$ $46 \mathrm{Mdal}$ Tc plasmid present in all six isolates, and by a $24.5 \mathrm{Mdal} \mathrm{Fi}^{-}$cryptic plasmid present in two of the six. The small plasmids could be transferred to $E$. coli independently from the self-transmissible molecules, suggesting that co-integration is not required for transfer, and that these two transfer systems are therefore members of the class 2 system of Anderson \& Natkin (1972).

Mobilization of the small non-conjugative plasmids ColE1 and CloDF13 by selftransmissible plasmids has been shown to require both an origin of transfer and the presence of transfer-promoting proteins encoded by the non-conjugative and self-transmissible plasmids (Warren et al., 1978; Van de Pol et al., 1978). Our inability to demonstrate mobilization of seven of the nine non-conjugative plasmids present in six $S$. sonnei isolates may reflect the absence of transfer origins recognizable by the gene products of the selftransmissible plasmids present. Alternatively, the non-mobilized plasmids may not specify the particular proteins required to interact with those encoded by the conjugative plasmids present to achieve mobilization. The size of the $1.0 \mathrm{Mdal}$ plasmid is sufficient to code for only one or two average-sized proteins. If each non-conjugative plasmid must code for proteins involved in its mobilization, then most or all of the information encoded by this plasmid would be required to facilitate its transfer.

This work was supported by grants from the Medical Research Council of New Zealand to P. L. Bergquist and D. A. Bremner. A. F. Jamieson was supported by a Medical Research Council of New Zealand Post Doctoral Fellowship. We thank M. J. Green of the National Health Institute, Wellington, for Shigella strains. 


\section{REFERENCES}

Achtman, M. \& Helmuth, R. (1975). The F factor carries an operon of more than $15 \times 10^{6}$ daltons coding for deoxyribonucleic acid transfer and surface exclusion. In Microbiology-1974, pp. 95103. Edited by D. Schlessinger. Washington: American Society for Microbiology.

Anderson, E. S. \& NATKIn, E. (1972). Transduction of resistance determinants and $\mathbf{R}$ factors of the $\Delta$ transfer systems by phage P1kc. Molecular and General Genetics 114, 261-265.

Bak, A. L., Christiansen, G., Christiansen, C., Stenderup, A., ØRSKOV, I. \& ØRSKOV, F. (1972). Circular DNA molecules controlling synthesis and transfer of the surface antigen K88 in Escherichia coli. Journal of General Microbiology 73, 373-385.

BREMNER, D. A. (1978). The transfer of antibiotic resistance by R-plasmids in Shigella. New Zealand Medical Journal 88, 9-10.

Chandler, M., Silver, L., Frey, J. \& Caro, L. (1977). Suppression of an Escherichia coli dnaA mutation by the integrated $\mathrm{R}$ factor $\mathrm{R} 100-1$ : generation of small plasmids after integration. Journal of Bacteriology 130, 303-311.

Christiansen, C., Christiansen, G., BaK, A. L. \& STENDERUP, A. (1973). Extra-chromosomal deoxyribonucleic acid in different Enterobacteria Journal of Bacteriology 114, 367-377.

Falkow, S. (1975). Infectious Multiple Drug Resistance, pp. 253-271. London: Pion Ltd.

Grinter, N. J. \& Barth, P. T. (1976). Characterisation of $\mathrm{SmSu}$ plasmids by restriction endonuclease cleavage and compatibility testing. Journal of Bacteriology 128, 394-400.

Jeppesen, P. G. N., Sanders, L. \& Slocombe, M. (1976). A restriction cleavage map of $\phi$ X174 DNA by pulse-chase labelling using $E$. coli DNA polymerase. Nucleic Acids Research 3, 1323-1339.

McDonell, M. W., Simon, M. N. \& Studier, F. W. (1977). Analysis of restriction fragments of T7 DNA and determination of molecular weights by electrophoresis in neutral and alkaline gels. Journal of Molecular Biology 110, 119-146.

Mandel, M. \& Hrga, A. (1970). Calcium-dependent bacteriophage DNA infection. Journal of Molecular Biology 53, 159-162.

Mayer, L. W., Holmes, K. K. \& Falkow, S. (1974). Characterisation of plasmid deoxyribonucleic acid from Neisseria gonorrhoeae. Infection and Immunity 10, 712-717.

Meyers, J. A., SANChez, D., Elwell, L. P. \& FALKow, S. (1976). Simple agarose gel electrophoretic method for the identification and characterisation of plasmid deoxyribonucleic acid. Journal of Bacteriology 127, 1529-1537.
Møller, J. K., Jørgensen, H. F., Christiansen, C., Christiansen, G., BaK, A. L. \& Stenderup, A. (1978). Characterisation of plasmids from wildtype Enterobacteriaceae. In Microbiology-1978, pp. 257-261. Edited by D. Schlessinger. Washington: American Society for Microbiology.

Pemberton, J. M. \& Clark, A. J. (1973). Detection and characterisation of plasmids in Pseudomonas aeruginosa strain P.A.O. Journal of Bacteriology 114, 422-433.

Porter, B. W., Kolodner, R. \& Warner, R. C. (1973). Plasmids of Shigella dysenteriae Y6R: a defective $\mathrm{Col}$ factor. Journal of Bacteriology 116, 163-174.

Rush, M. G., Gordon, C. N. \& Warner, R C. (1969). Circular deoxyribonucleic acid from Shigella dysenteriae Y6R. Journal of Bacteriology 100, 803-808.

Smith, H. R. \& LingGood, M. A. (1970). Transfer factors in Escherichia coli with particular regard to their incidence in enteropathogenic strains. Journal of General Microbiology 62, 287-299.

Smith, H. R., Humphreys, G. O. \& Anderson, E. S. (1974). Genetic and molecular characterisation of some non-transferring plasmids. Molecular and General Genetics 129, 229-242.

SoutherN, E. M. (1975). Detection of specific sequences among DNA fragments separated by gel electrophoresis. Journal of Molecular Biology 98, 503-517.

Stahlly, D. P., Dingman, D. W., Irgens, R. L., Field, C. C., Feiss, M. G. \& Smith, G. L. (1978). Multiple extrachromosomal deoxyribonucleic acid molecules in Bacillus thuringiensis. FEMS Microbiology Letters 3, 139-141.

TANakA, T. \& Weisblum, B. (1975). Construction of a colicin E1-R factor composite plasmid in vitro: means for amplification of deoxyribonucleic acid. Journal of Bacteriology 121, 354-362.

Thompson, R, Hughes, S. G. \& Broda, P. (1974). Plasmid identification using specific endonucleases. Molecular and General Genetics 133, 141-149.

VAN de Pol, H., VeltKamp, E. \& NiJKamp, H. J. J. (1978). Genetic analysis of the mobilisation of the non-conjugative plasmid CloDF13. Molecular and General Genetics 160, 139-149.

Warren, G. J., Twigg, A. J. \& Sherratt, D. J. (1978). ColE1 plasmid mobility and relaxation complexes. Nature, London 274, 259-261.

Zasloff, M., Ginder, G. D. \& Felsenfeld, G. (1978). A new method for the purification and identification of covalently closed circular DNA molecules. Nucleic Acids Research 5, 1139-1152. 